\title{
Violence and Predation in Late Medieval Mediterranean Europe
}

\section{Citation}

Smail, Daniel Lord. 2012. Violence and predation in late medieval Mediterranean Europe. Comparative Studies in Society and History 54(1): 7-34.

\section{Published Version}

doi:10.1017/S0010417511000570

\section{Permanent link}

http://nrs.harvard.edu/urn-3:HUL.InstRepos:9296588

\section{Terms of Use}

This article was downloaded from Harvard University's DASH repository, and is made available under the terms and conditions applicable to Open Access Policy Articles, as set forth at http:// nrs.harvard.edu/urn-3:HUL.InstRepos:dash.current.terms-of-use\#OAP

\section{Share Your Story}

The Harvard community has made this article openly available.

Please share how this access benefits you. Submit a story.

Accessibility 
Violence and Predation in Late Medieval Mediterranean Europe ${ }^{1}$

Daniel Lord Smail
Department of History
Harvard University
Cambridge, MA 02138
smail@,fas.harvard.edu

June 2011

Abstract. The historical literature on state-formation in late medieval and early modern Europe has suggested that a coercive apparatus consisting of courts, prisons, and police emerged in an uncomplicated way from the state's interest in the repression of violence. Using the cities of Lucca and Marseille as case studies, this article demonstrates that some jurisdictions, during a formative period of state formation, were surprisingly handsoff in their approach to interpersonal violence. In the fourteenth century, both cities do display well-developed infrastructures of coercion. The target of these coercive institutions, however, was indebtedness, not criminal justice. The principal argument of this article, therefore, is that debt recovery was a major engine for the growth of a coercive apparatus in late medieval Mediterranean. The agency lying behind this process was not the unitary agency of thinking, planning, "colonial" state but rather the fragmented agency of myriad private creditors.

In the full-text databases of Latin sources from Europe from the period between 400 and 1500, the Latin word for violence crops up around two thousand times, about as often as "justice" $(2,400)$ though not as often as other interesting words like "envy" 
$(6,000)$ or "vengeance" $(3,800) .^{2}$ The frequency of use of the word, adjusted for the vagaries of survival, reveals an interesting trend. From the tenth to the eleventh century, an age of predatory castellans and violent territorial expansion, the frequency nearly doubles in the extant literature, and remained high for several centuries to come. The word often appears in texts alongside nauseating tales of violence, of hands lopped off and eyes plucked out and intestines dragged from their hidden recesses. There's the story told by Guibert of Nogent about the predatory castellan Thomas de Marle, who hung his captives by their testicles until the weight of their own bodies tore them off. ${ }^{3}$ These were exempla. They painted verbal pictures of the behavior of those who were surely doomed to hell. In the hands of clerical authors like Guibert, they served as a goad to kings and princes who, in their indolence, might allow this stuff to go unavenged.

Over the course of the late nineteenth and early twentieth centuries, even as Max Weber was setting down his sociology of power, historians collected a host of such vignettes and stuffed them into sourcebooks, histories, and lectures, where they have remained ever since. ${ }^{4}$ By putting on display the brutal violence deemed typical of medieval Latin Christendom, historians sought to provide students and citizens alike with compelling reminders of the failures of a world without states. The suppression of irrational or impulsive violence, the product of what Marc Bloch once called "emotional instability," was thus the great achievement of Western civilization. ${ }^{5}$ According to the model, kings and communes first began to respond to the problem of violence in the twelfth century. From the thirteenth century onward, the violence of figures like Thomas de Marle was being met, and crushed, by the overwhelming counter-violence of kings, princes, and communes. Sovereign states invested in prisons and policing agents. They 
enacted statutes that at first narrowed and then eliminated altogether the right to vengeance. Newly minted laws criminalized the many kinds of violence, ranging from bloody homicides to the merest insult. Inspired by Roman precedents, penal law came up with a range of gruesome and humiliating punishments for violent offenders, the better to deter future crime. ${ }^{6}$ Women buried alive for murdering their husbands. Felons broken on the rack, the body dragged through town on the hurdle, then hoisted on the wheel. Jews hung upside down to die between two dogs. ${ }^{7}$ Ears, hands, and feet lopped off. Brands applied to the foreheads of thieves. This is to say nothing of judicial torture.

At the heart of this transformation from private violence to public counterviolence, according to the standard model, was a system of justice centered on the body and its pain. This system did not give way, in Michel Foucault's variation on the standard model, until the emergence of the Panopticon in the nineteenth century, when the body was still coerced but in a different way. Critics have pointed out the flaws in Foucault's reasoning, and other schemes abound. ${ }^{8}$ But many observers have agreed with Foucault that pain was a fundamental symbol of the premodern penal system, and that the body, as Foucault put it, was "the major target of penal repression." 9 Old Regime sovereignty, in this model, was built on the rumors of torture and the spectacles of punishment that displayed the frightening capacity of the state to visit violence on the bodies of its subjects. ${ }^{10}$

For decades, medieval European historians found the model helpful, for it gave them reason to locate the origins of the state and civility in medieval institutions. Then came the revolution. In the early 1990s, as the harvest of post-modernism began to fill the pages of medieval scholarship, interest in violence exploded among medievalists. Over 
the space of a few short years, articles and books in the area of medieval studies containing the word "violence" in their titles increased nine-fold in frequency. Almost without exception, what this literature has queried is the idea that violence was impulsive and mindless. The trend today is to explain violence as political, strategic, and calculating. As one collection has put it, "violence was not an expression of the irrationality and extreme emotions of medieval people but a product of their rationality, a behaviour well understood and strategically deployed." "Thomas Bisson, in this vein, describes the violence of castellans like Thomas de Marle as a method of lordship and an order of power. ${ }^{12}$ Chris Wickham has shown how violence was a strategy that helped promote certain kinds of legal claims, since an unwillingness to be reasonably violent in twelfth-century Italy hinted that you really weren't confident about your rights. ${ }^{13}$ William Ian Miller has suggested that the heroic figures of saga Iceland accepted violence as the price of personal liberty. ${ }^{14}$ Robert Bartlett has argued that the otherwise incomprehensible violence practiced by eleventh-century Norman mercenaries in Sicily was a performance finely calculated to spread the rumor of Norman violence and thereby cow their adversaries. $^{15}$

The new school of thought has done much to recuperate the period before 1200 as an actual society rather than a Lord of the Flies anarchy. If customary vengeance flourished in the early and high middle ages, that was because it formed part of a legal system. ${ }^{16}$ By restoring the logic of violence, moreover, historians have exposed the hidden motives of kings and states. The emerging monopoly on the legitimate exercise of coercive force, in this view, had nothing to do with a sovereign desire for peace. The state was instead born in sin and violence. ${ }^{17}$ States repressed everyday violence out of a desire 
to generate spectacles of power. They sought monopolies of violence in order to deploy violence against their many enemies, both real and imagined. The historians who once celebrated the growth of coercive central authority, in an unbroken continuum from Suger of St. Denis to the present day, now come across as dupes of a clever propaganda campaign lasting 800 years and counting.

Yet for all their differences, the models proposed by the old and new schools are fundamentally the same. The old school offered a colonial vision of the state as an agent of civilization, where the system of coercion was a key component in the state's effort to bridle the violence of the primitive. The new school, reversing the moral polarity, offers a postcolonial vision of the state as a self-conscious agent of domination, where the system of coercion is a convenient device for the display of sovereignty. Both schools share the hyper-statist assumption of the colonial narrative. But do colonial narratives work in medieval contexts?

By all accounts, it was during the later middle ages, from 1250 to 1500 , that the infrastructure of coercive central authority made its appearance. Statutes, customaries, commentaries, images and artifacts: the evidence conspires to suggest that the growing state monopoly on violence and the sovereign domination of the body unfolded in a straightforward and uncomplicated way. Or at any rate, this is what the normative evidence suggests. In recent years, a different picture has emerged from the archival evidence. Everywhere we look in later medieval Europe, from Florence and Valencia to England and the Low Countries, among Christians, Jews, and Muslims, layfolk and clerics, men and women, we find not only practices of vengeance, but persistent expectations or assumptions of the rightness of vengeance. ${ }^{18}$ Confronted by vengeance, 
moreover, sovereigns looked the other way. Combing through the archives of the Parlement of Paris, Claude Gauvard came across letters of pardon and grace issued in their tens of thousands by the late medieval kings of France to men and sometimes women who killed and maimed in hot or cold blood. ${ }^{19}$ The foundations of royal majesty, she argued in her magisterial 1991 work, were erected not so much on the spectacle of punishment as on the power to reprieve the penitent from the rigors of local justice.

The time has come to cast off the grip of the colonial narrative and write the history of sovereignty, violence, and coercion in the later middle ages on its own terms. In this article, I want to show that the repression of everyday violence was not always a major preoccupation of late medieval jurisdictions. The courts of law in the two cities examined here were most certainly developing an apparatus of coercion, including prisons, court stenographers, and dozens of strongmen. In their daily rounds, these men, the crier-sergeants, inflicted countless acts of coercion and humiliation. But their principal target was not private violence. What generated much of their violence was the condition of indebtedness. Whence the major claim of this article: the regulation of debt stimulated the growing apparatus of coercion in later medieval Europe. In Mediterranean Europe, it was far more influential than the repression of interpersonal violence.

As case studies, I shall use the cities of Lucca and Marseille in the fourteenth century. ${ }^{20}$ These were mid-sized cities with populations hovering around 20,000 to 25,000 before the Black Death. The former was a center of banking and silk production; the latter a port town. Both cities cast a political and economic shadow over a sizable territory with relatively well-defined boundaries, although neither enjoyed the political autonomy of Florence or the German imperial cities. Marseille, in the fourteenth century, 
was a stable possession of the distant and declining Angevin crown of Naples. ${ }^{21}$ Lucca's history in the fourteenth century was more turbulent; after the death of the Castruccio Castracani in 1328 the city became a political football kicked around between Pisa, Florence, and other foreign powers until the return of some degree of autonomy in 1369. ${ }^{22}$ Both cities followed Roman-canon law. Both cities, moreover, followed a nearly identical set of unwritten customary procedures that had grown up inside the trellis provided by Roman-canon procedural law. The late medieval archives of both cities, finally, have preserved an appallingly rich body of sources: thousands of registers, often hundreds of pages in length. These offer genuinely fine-grained perspectives on the practice of justice in the fourteenth century. They allow us to reconstruct patterns that are less visible in the equally voluminous but rather coarse-grained documentation extant from the great kingdoms of northern Europe.

The argument proceeds in two phases. The first, centered on penal justice, explores the widespread practice of contumacy: the custom of responding to a criminal summons with flight. Contumacy matters for a very simple reason: where there is no body to put on trial and punish, the court cannot mount a spectacle of violence. Although the proportion of contumacious individuals in fourteenth-century Mediterranean Europe varied from region to region, the custom itself was ubiquitous. If the accused has fled, the only possible sentence, apart from the automatic banishment, was a very large fine, soon transformed into a lingering debt. In a curious way, courts did not respond to violence with counter-violence. They responded to violence with debt.

Everywhere, historians of late medieval justice have noticed that the debt to society was paid in the currency of coin more often than the currency of pain. 
Everywhere, the phrases used to describe the practice of fines invoke images of failure, greed, inefficiency, or expedience. These invocations reveal a reflexive adherence to the idea that the state, if it is to be a state, must inflict violence on the body. But the idea that a monetary fine represents a failure of justice is gross anachronism. It arises from a misunderstanding of the coercive possibilities of indebtedness. The condition of being in debt allowed for coercion in multiple dimensions, ranging from neighborly gossip to imprisonment for debt. In the second section of this article, I shall pay special attention to one of the least explored elements of debt recovery, namely, the practice of seizing or distraining goods for the repayment of debt. I call this "predation," from the Latin word used by the Lucchese courts, namely, preda, which means booty or plunder or prey. In a spectacle every bit as scripted as the more familiar spectacles of pain and humiliation, the crier-sergeants charged with debt recovery would invade homes, seize their prey (prede), and cart them off. The prey consisted of clothing, fabrics, finewares, tools, barrels, comestibles: practically everything that could move. Though words varied from one jurisdiction to the next, the custom of predation was universal in later medieval European jurisdictions. $^{23}$

Predation was a state-sponsored spectacle of violence. More accurately, predation was a service, bureaucratically bound up, packaged, and sold to creditors in exchange for a small fee consisting of a percentage of the debt. Charles Tilly has invited us to think about the state as a protection racket. ${ }^{24}$ I propose an equally ironic image: the state as a collection agency. The creditors who purchased this service included ordinary people, women and men, Christians and Jews, along with great property lords and professional moneylenders. Some creditors in all probability were in debt to others, since the late 
medieval culture of debt should be seen as a complex web of relations rather than a system of classes. Some debts originated as loans and deposits; others sprang from sale credits, unpaid rents and legacies, and a host of other obligations. The scale of the practice, in the cities I have studied, was startling. Predation exceeded, by distance, other vectors of court-sponsored violence. Spectacles of predation outstripped penal spectacles of pain and humiliation by several orders of magnitude.

So yes, things that look like states were hastening to develop a monopoly on the legitimate exercise of violence in the later middle ages, using debt recovery as the symbolic field for the creation of sovereignty. Perhaps hyper-statist assumptions are correct after all. Yet the appearance of intention and design always dissolves when the analysis is carried out at a higher resolution. ${ }^{25}$ Where debt recovery is concerned, here is the key: it was the interests of creditors, not states, that drove the process. Private debt recovery was primarily responsible for building the prisons, police forces, and other features of the apparatus of coercion in late medieval Mediterranean Europe. Sovereignty simply came along for the ride. Here, the putative state interest in acquiring a monopoly on coercion dissolves into untold thousands of acts of petty interest. In exploring the fragmentation of agency that characterizes this situation, we can appreciate first-hand the perils of applying colonial narratives to late medieval contexts.

\section{II}

Four incidents from Lucca. The year is $1335 .^{26}$

1. Cyia, the wife of a certain Stefanello, struck another woman in the head with a small dagger, drawing blood. The court issued a summons, but "she did not come, but instead was contumacious" (non venit sed potius 
contumas existit). The court banished her and assessed a fine of $£ 10$.

2. Fiore, the wife of Giacomo, struck another woman on the nose, drawing blood. The court issued her a summons as well, but she too was contumacious (non venit sed pottius contumas existit). She was banished and fined $£ 5$. An additional note records that in 1338 , she made peace with her enemy, a record of which was notarized. She was allowed to pay 10s., a tenth of the original sum.

3. Cecchora, staff in hand, came against a crier-sergeant of Lucca named Coluccio Lupori, who had come to the village of Deccio to seize prey from her husband (volendo... eius virum depradari et predam ei elevare). She then shut the door in his face. She, too, was contumacious, as the now-familiar phrase reveals (non venit sed potius contumas existit), and was banned and fined 20s. A note records a cancellation of the ban in 1338 following receipt of payment.

4. Gianus, son of the late Symus Salamonis, was accused of fraud by the widow Nesia. Pretending to be her children's guardian, he made off with some goods, claiming they were items left in pawn. The items consisted of two sheets, two tablecloths, a tunic with silver buttons, a skirt made of red and green muslin, and a bolt of muslin cloth; he sold the lot for $£ 40$. Summons were issued; he was contumacious (non venit sed pottius contumas existit), banned, and fined $£ 100$. The ban was canceled after he paid a fine of 20 s., a hundredth of the original. 
These stories are found in the first few folios of a register of the criminal court of the Podestà di Lucca. They illustrate the banality of contumacy. A considerable proportion of the men and women accused by Lucca's criminal court of violence, fraud, or theft simply failed to show up for the initial hearing. They were declared contumacious, which resulted in an automatic sentence of banishment and a fine. For the notaries and judges of the Lucchese court, the practice was routine.

Late medieval and early modern legal and social historians have repeatedly noted the existence of contumacy in towns and cities throughout Europe. ${ }^{27}$ Some have been tempted to use the contumacy rate as a proxy for a more general failure to police. ${ }^{28}$ "Medieval states were notoriously inefficient, and judicial and police institutions of only limited efficacy," remarks one set of authors. ${ }^{29}$ Another historian, commenting on the high levels of violence in early modern Europe, notes the lack of centralized police agencies and an "inadequate range of local police operatives." $" 30$ These suggestions of inefficiency and inadequacy are founded on the not-unreasonable expectation that late medieval states actually wanted to police their populations. So here, then, is the question: were criminal procedures in cities like Lucca and Marseille based on an expectation of pre-trial detention?

The four cases offered above, mere summaries, are too insubstantial to provide answers. Happily, the original proceedings of many criminal inquests do survive in the voluminous Lucchese criminal archive, in the form of registers or day-books that meticulously recorded the stages of each trial. From these registers, we can establish a set of customs that operated within the interstices of the procedural law, and get a better sense of the activity of the crier-sergeants. 
All inquests began with a denunciation made either by the victim, an interested party, a local official, or personnel of the court itself. The denunciation was immediately followed by a summons (citatio), a procedure whereby crier-sergeants went to the houses or neighborhoods of the accused and called them to court. It is important to note this sequence: summonses were necessary because the men and women accused of crimes of violence were almost never incarcerated in the immediate aftermath of the conflict.

Did the accused respond obediently to the summons? Consider, by way of example, a typical case, this one initiated on 3 January $1334 .{ }^{31}$ Ten men from the countryside around Lucca were accused of committing egregious acts of violence and theft. Witnesses were named and a single crier-sergeant was sent to issue the first of the summons required by procedural law. The crier-sergeant returned and reported that he had personally sought out each of the accused, in their homes, and to each he had delivered a summons, ordering him to appear at court the next day. The men, who paid no attention whatsoever, were found in contumacy, and a marginal note records that they were all banished on 22 January and sentenced to decapitation and to restitution of the stolen goods.

The sequence of events outlined here is characteristic of almost every case of murder, grievous injury, professional theft, and banditry in a sampling of registers drawn from the Lucchese criminal archive from the 1330s. But let me draw attention to an especially noteworthy feature of this record: there is no ambiguity about the fact that the crier-sergeant stood face to face with each of the ten men while issuing a summons. It was not his job to make an arrest. It is possible, of course, that the crier-sergeant was lying to the notary when he claimed that he spoke personally to each of the men. But 
there was, in fact, little temptation to lie, since procedural law did not demand a face-toface encounter with the accused. Summonses could be issue to the family of the accused; in cases where the accused was not a resident of Lucca or its district, a public crier delivered the necessary summonses in all the public places of Lucca. ${ }^{32}$

Contumacy in Lucca and Marseille always resulted in an ex post facto sentence of banishment coupled with a large fine. In Marseille, the fine was considered a contumacy fine: the individuals banished in this way were technically guilty of contumacy, not murder or assault. In Lucca, things were a little different, since a provision in the statutes allowed the commune to consider contumacy tantamount to a confession of guilt. ${ }^{33}$ The scale of banishment, at least in Lucca, was significant. In the 1330s, lists of banishments kept by the court reveal that several hundred individuals were banished per year. A partial register from 1333 includes 42 banishments in two months, equal to an annual number of around $250 .{ }^{34}$ In 1337 , the register of banishments, which has every appearance of being complete, lists 191 men and 4 women banished in six months, or close to 400 per year. ${ }^{35}$ It is difficult to know how long banishment lasted, and it is clear that the length of time in exile varied considerably from one person to the next. Marginal notes in the 1337 register show that 67 of 195 exiles straggled back over the ensuing six years, leaving 128 out in the cold. Others, surely, slipped back to their homes. But even so, the impact of banishment was demographically significant. An awareness of the threat of depopulation and declining tax revenues is revealed in the fact that both Lucca and Marseille issued blanket amnesties from time to time. In Lucca, these amnesties were sometimes coupled with steep discounts in the contumacy fine in an effort to lure back citizens. 
The scale of banishment means that the court itself did not often make pre-trial arrests. This does not mean, however, that the court did not have a system of pre-trial detention. The reason is that the accused occasionally chose to obey the summonses to appear in court. Consider a register of the criminal court from 1339-1340, which is especially well preserved and meticulous in its construction. ${ }^{36}$ This register recorded 74 inquests in five months. In a number of cases, especially those involving violence, the accused consisted of both individuals and groups. In 33 inquests, including all of the homicides and other grave injuries as well as one case of arson and another of blasphemy, the accused individuals or parties were contumacious and received an automatic sentence of banishment. In two inquests involving groups of men, the results were mixed; some came, some did not. If we leave aside the two mixed cases, the rate of initial contumacy was 33 in 72 (46 percent). In the remaining thirty-nine inquests, the accused showed up voluntarily at court in response to the summons. In fourteen cases, the accused (individuals or groups) were incarcerated while awaiting trial. In fifteen cases, the accused relied on oathswearers (fideiussores) to provide bail. ${ }^{37}$ In six cases involving fairly minor offenses, the accused were released, and in the remaining four the results were mixed.

Table 1: Outcome of Summons in Criminal Inquests in Lucca, 6 October 1339 to 8 March 1340

\begin{tabular}{lc}
\hline Result of the initial summons & No. \\
\hline Appearances of the accused at court, resulting in: & 39 \\
Incarceration & 14
\end{tabular}


Bail

Immediate release

Mixed results involving groups of accused

Contumacy, resulting in banishment

Mixed results involving groups of accused
15

6

4

2

Total 74

Source: Archivio di Stato di Lucca, Podestà di Lucca 4739

In Marseille, certain customs ran parallel to those we find in Lucca. Almost all

cases of homicide resulted in contumacy. ${ }^{38}$ In other respects, however, Marseille differed significantly from Lucca. First of all, Marseille's crier-sergeants were more active in making arrests in cases involving street violence. Witness depositions in some of the extant cases, for example, often conclude by noting that sergeants arrived in time to separate the fighting parties and, on occasion, took them off to jail. Some indication of the policing energy exerted by the court can be gained by examining the source of the denunciation: where the denunciation that generated an inquest was made by a sergeant, we can suppose that an arrest had been made; where the denunciation was instead made by a neighbor or the victim, it is less likely that there had been an arrest. In the sole surviving register of Marseille's criminal court, from 1380, there are forty-four cases involving a bodily assault. In twenty-eight, the denunciation that set the criminal proceedings in motion was made not by a sergeant but instead by an interested party, often the victim. In four more, the case was initiated by public opinion. In the remaining twelve cases (27 percent), therefore, it is likely that the sergeants arrived in time to witness the fight and perhaps to seize the parties involved. A significant percentage of the 
arrests that constables did make involved fights that arose in the prostitutes district, which was located just a stone's throw from the court itself. We can posit the existence of a small halo around the court in which the sergeants could and did act with dispatch.

Marseille also differs significantly from Lucca in its rate of contumacy, which was considerably lower than the rate typical of Lucca. Although the near-total destruction of Marseille's criminal court archive makes it difficult to suggest any figures, we can get some idea of local custom from the several extant registers of fines issued by the court and preserved in the records of the city's treasurer. Whereas in Lucca, the threshold of contumacy was very low-even slaps, insults, and minor head wounds, such as the blow that Cyia delivered to her victim, were capable of generating contumacy-few Massiliotes ignored a summons for acts of petty violence or insult. Hundreds of cases of minor blood-letting fill the pages of the records of fines assessed. Rather than thumb their noses at the court, in other words, violent offenders in Marseille simply came to court, paid their fine and got on with it. In the sole surviving register of Marseille's criminal court, we find only four cases of contumacy among the eighty-four inquests, for a contumacy rate of just under 5 percent. ${ }^{39}$

What explains the striking variation in contumacy rates? It is tempting to attribute the variation to Lucca's failure to police. The spectacle of Lucca's crier-sergeants greeting men and women at their doorsteps and issuing a toothless summons for homicide, assault, or theft suggests a failure of nerve. But the argument runs up against an uncomfortable fact. In Marseille, the more serious the crime, the less likely it was that agents of the court would arrest the accused. In cases of homicide, the custom of sanctuary and self-exile was almost universal. If Marseille’s criminal court was serious 
about criminalizing and prosecuting violence, we should expect the opposite result.

The key to understanding why contumacy rates varied so dramatically between Marseille and Lucca does not lie in the courts. It lies in the culture of peacemaking. As a rule of thumb, contumacy and flight in both cities were triggered when an incident crossed over the threshold distinguishing commonplace injuries from injuries that required an act of peacemaking. In Marseille, the threshold of peacemaking was very high. Notarized peace acts from Marseille, accordingly, are exceedingly rare: there are only eight such acts to be found among the more than 6,600 notarial acts extant from the mid fourteenth century. ${ }^{40}$ In Lucca, the threshold of peace-making was very low. We have already seen how Fiore's act of violence was innocuous enough to attract the smallest of fines. She nonetheless followed the path of contumacy, and at some point during the period of her nominal banishment, between 1335 and 1338, she made peace with her victim. Returning to the court, she showed them the notarized peace act, and was rewarded with a considerable reduction in her fine.

Hers was one of many such cases hinting at the peace-making procedures that lurk behind many cases of contumacy. On 19 October 1339, for example, the Lucchese court opened an inquest into a man accused of striking another on the face with his hand. ${ }^{41}$ No blood was drawn, although the record carefully noted that the incident took place on a public way. Two summonses were issued, and then on 25 October the accused was banished. Four days later, however, he appeared at court and allowed himself to be imprisoned. At a hearing on 2 November, he showed the court a notarized peace act; a few days later he was condemned to a relatively heavy fine of $£ 45$. Contumacy, in this case, allowed the aggressor time to make peace with his victim. In his case, the process 
required only ten days. In Fiore's case, several years were needed, perhaps because the wound was light and the matter wasn't pressing. There are cases of homicide in Lucca where peace negotiations lingered on for years.

At the same time, it is likely that the accused were finding ways to test the waters and learn, in advance, how the court might treat them if they returned. In 1334, a register covering the first six months of the year includes fifteen criminal cases. ${ }^{42}$ Twelve of the parties summoned failed to respond to the initial summons and were declared contumacious, for a contumacy rate of 80 percent. Six of the contumacious individuals, however, showed up within days, and three of them, including a man accused of rape, were then clapped in jail. Three of the six, including the rapist, were found guilty, but the fines they were given were relatively small. Although we can't know for sure, the sequence of events suggests that the contumacious individuals were not only negotiating with the victim or his or her family; they were also negotiating informally with the personnel of the court.

During the entire period of banishment, whether it lasted days or years, the banished person was, quite literally, an outlaw. In cases involving homicide, he (very rarely she) could be killed with impunity. Clues suggest that some victims' families took advantage of this precarious legal condition. A register preserved in a series known as "The Court of the Rebels and the Banished" from 1334 lists 615 men euphemistically described as "absent" from the city of Lucca. ${ }^{43}$ The point of the register was fiscal: the treasury wanted to know which men were not paying the tax. Some of the absentes may have been debt fugitives or political rebels, but most had fled the city following a serious crime. From time to time a change of circumstances led to a short note entered into 
spaces left after the names. "He is in Lucca because he paid up." "He is in Lucca and he paid up, with peace." "He is in Lucca and has settled with the father and the brothers." "He settled with the brothers." Underneath a number of names the notary has written: "Dead." This laconic entry is telling us two things. First, men in exile were following the statutory provisions found in Lucca, Marseille, and every other city or commune in southern France and Italy to the effect that killers or assailants must not return home until they can prove that they have established a peace with their victims. We have great drifts of these peace acts from all over late medieval Italy. ${ }^{44}$ Second, the family and friends of the victim occasionally got to their adversary before the peace was established.

Although contumacy was the norm, we find the occasional counter-example. On 3 December 1339, two men accused of fighting chose not to be contumacious; they responded voluntarily to the summons and were incarcerated for two days. While in prison, they made peace with each other, and were released on 5 December after paying fines. ${ }^{45}$ But cases like this, where the accused party responded to a summons and then made peace, are uncommon. Cases involving incarceration or bail, in fact, rarely led to peacemaking. In some cases from Lucca, the accused responded obediently to the summons because he wished to contest the charges. In other cases, the accused simply admitted the charges and paid the fine without making peace, the norm in Marseille. On 9 December 1339, a man who drew blood during the course of a fight appeared in court in response to a summons. He confessed his guilt and found an oathswearer. On 16 January 1340, he was condemned to a fine of some $£ 28$ in Marseille’s currency, which he paid. Although the injury lay within the spectrum of injuries meriting peace, there is no hint of peacemaking. 
Why not? The answer is that peacemaking was not a dry and bureaucratic procedure. It was an act of contrition that required the assailant to humiliate himself or herself. In Marseille, extant peace acts reveal men, on their knees in church, begging for peace from their victims or the victims' kinfolk in the front of the entire congregation. Peace was also potentially shameful for the peace-giver as well, a sign of weakness or lack of manliness. Finally, because peace created a rough equivalency between the two parties, the procedure did not apply to situations where the two parties were of very different social standings. There were, in short, numerous obstacles to peacemaking. The decision to confess to a charge and pay a fine was therefore a decision to abandon the way of peace.

To sum up, the criminal courts of Lucca and Marseille did not see it as their task to regulate violence through counter-violence, coercion, and arrest. Crier-sergeants were involved to some degree in keeping the peace, but the expectation of contumacy means that many criminal inquests, especially in Lucca, unfolded in the absence of the accused. Tellingly, the more serious the crime, the more likely it was that the accused was absent. This is not to say that courts weren't interested in regulating violence. But the courts did it indirectly. In both Lucca and Marseille, the criminal justice system put the squeeze on the accused, and coerced them into making peace. The humiliation of the assailant was achieved but far more often through the ritual of peacemaking than through public rites of shaming.

III

To perform the work of violence and publicity that is essential to justice, the judges and notaries of Lucca's law courts drew from a common pool of crier-sergeants. 
By statute, fifty were to be elected each year by the General Council. ${ }^{46}$ This is close to the actual number used: a search through the several dozen registers extant from 1338 reveals the activity of some fifty-seven criers. Around half of these worked almost exclusively for the criminal and civil chambers of the principal court, the Podestà di Lucca; the others performed duties for the remaining seven courts. Though the criers in this latter group worked for multiple courts, they tended to gravitate toward one. In the 1338s, for example, a crier-sergeant named Vannes Lazari worked for at least three courts, but he much preferred the Curia de Treguani, delivering around 180 of that court's libelli over the course of the year.

The abstract concept of coercion was manifested in the actions of the criersergeants and their associates, the berroarii. We know they spent a good deal of time facilitating the business of the criminal court, issuing summonses in neighborhoods and villages. Occasionally, they made an arrest and marched the accused off to jail to await trial. Crier-sergeants also delivered public announcements on a daily basis, for this was a world in which important news traveled by word of mouth. But of all the daily tasks they performed, it is debt recovery that stands out. Debt recovery, not a major preoccupation of courts of law in Mediterranean Europe before 1200, emerged in the thirteenth century in tandem with the expansion of commercial and consumer credit. For our purposes here, the crucial feature of the system of debt recovery is that creditors had access to two forms of coercion. First, they could have their debtors incarcerated, a threat serious enough that debtors, like murderers, often took to self-imposed exile in an effort to escape it. ${ }^{47}$ Second, they could ask for a predation of the debtors' goods.

Imprisonment for debt was widely practiced in early modern and nineteenth- 
century Europe. ${ }^{48}$ Important new work has shown the prevalence of the practice in later medieval Europe. ${ }^{49}$ In Marseille, fragments of evidence hint at the scale of incarceration for debt. Here, four agricultural workers have their employer imprisoned for nonpayment of wages. ${ }^{50}$ There, a Jew is imprisoned, perhaps for reasons arising from his wife's illicit sale of items left in pawn. ${ }^{51}$ In 1325 , a citizen of the lower city and his family shift their residence a few blocks away to the Praepositura, an entirely different legal jurisdiction, so as to avoid imprisonment for debt, although the court, unimpressed by this legal nicety, arrested him anyway. ${ }^{52}$ Merchants, fearing the flight of their erstwhile business partners, have them imprisoned: in 1341, a wine-seller had one of her clients imprisoned for a debt of $£ 7,12 \mathrm{~s}$, and $2 \mathrm{~d} .{ }^{53}$ In 1354 , the sub-vicar, an official who was, in effect, the head of Marseille's police force, was himself arrested and imprisoned for a large debt of some $£ 42$ owed to a draper. ${ }^{54}$ In 1335 , a man, indebted to numerous creditors, was thrown in jail; his own wife then sued him, successfully, for the return of her dowry. ${ }^{55}$ We also have records showing that people stood surety for friends, husbands, or clients who had been imprisoned by their creditors. ${ }^{56}$

The richer Lucchese records provide a better sense of the practice. Between January and June of 1333, the crier-sergeants of the court of the Podestà arrested and brought 103 men into debtors prison, or around 200 per year. ${ }^{57}$ Not all of these were imprisoned. Marginal notes tell us that thirty-eight of them were released on the same day, most benefiting from the intervention of oathswearers who stood surety for them. In this case, the act of imprisonment was a device used by creditors to bind their debtors into webs of obligation that could be tapped later. In seven cases, debtors were released immediately through an act of grace extended by their creditors. It does not take much of 
an imagination to see the transaction in a different light: thugs sent around to rough up a debtor and give him a taste of worse to come. Indeed, it could be worse, as we see in twenty cases where the debtors languished in jail for an average of around two weeks before the offer of grace was extended. A few cases were especially onerous, three extending for over seven weeks. In one case, a small debt of $£ 510$ s. landed a debtor in prison on 15 March 1333; there he stayed until, by a stroke of immense good fortune, his creditor died. The man's heirs released the debtor on 4 June. Curiously, the marginal note tells us that they had received satisfaction for the debt, as if the debtor and his creditor were entangled in some obscure moral contest.

In eight cases, the reason for the release was not given. Strikingly, only in three cases are there marginal notices indicating that the debt was actually paid, including the one above. In one case, a debtor imprisoned on 1 February was released after twelve nights in jail, on 12 February 1333, when the creditor announced himself satisfied for his credit of $£ 59$ s., plus the unlisted expenses generated by the process of recovery.

These are the cases where a release date is indicated. Thirty-four cases include no such marginal notation. It is not easy to know what to make of them. For one thing, the notations are haphazard enough as to suggest that some were simply not made. But none was recorded after 30 June, so any release made in the second half of the year would not have been entered in this register. It is very likely that some of these unfortunates stayed in jail beyond 30 June; very likely, in other words, that the median duration of imprisonment was longer, perhaps considerably longer, than is suggested by the extant records.

Some insight into the population of the debtors' prison at any given moment can 
be gleaned from an act of testamentary charity offered in 1340 by Giacomo, son of Bindus Galbanetti, who left a series of legacies in his testament dedicated to acts of charity for the poor. ${ }^{58}$ Included among his bequests was a sum of $£ 300$ to purchase grace for all debtors currently in prison, forty-four in number. The debts listed ranged from $9 \mathrm{~s}$. to $£ 39$ ( 780 shillings), i.e. a range similar to what we found in the register of the Court of the Podestà in 1333. The forty-four debtors found by his executors, naturally, represent only a fraction of the total number of debtors imprisoned on an annual basis.

The debts recorded in the fiscal account generated by Giacomo's legacy were a varied lot, expressed in florins, Lucchese pounds, and, in some cases, grain or oil: the latter, presumably, were unpaid rents in kind. Some eighty-two are legible and can be readily translated into Lucchese shillings at the going rate. ${ }^{59}$ The average debt was 764 shillings, i.e. $£ 38$ 4s. or just over 11 florins, although the median was far lower, 435 1/2 shillings. The smallest debt, one and one-half bushels (staria) of wheat, was worth just under a pound; the highest, one of several that skew the mean, was a merchant's debt of $£ 273$ 12s. 6d. for a shipment of muslin.

The drainage basin for the currents of debt that flowed into the Lucchese courts extended well beyond the walls of the city. On 25 February, to take an example, the court authorized a crier-sergeant to arrest the entire population of Loppeglia, a village located in the hills to the north of Lucca, for a collective debt of $£ 2217 \mathrm{~s}$. In the event, the crier, who was working alone that day, took only two representatives of the village back to jail. Although debtors' residences were not often given, probably a third of the incarcerated debtors were from Lucca itself.

The arrest itself cost money ${ }^{60}$ In Marseille, a fragment of evidence hints at the fees 
involved. In 1357, as noted earlier, four workers had their employer Fulco Clement imprisoned for non-payment of wages. One of the men should have been paid 4 albos for two days of labor, and a woman should have earned 2 albos over the same period. An albus was a coin roughly equivalent to a shilling. They subsequently sued him to recover the debt, and the resulting record includes a list of court costs which they wished to charge to Fulco. Included was this notation: "For having Fulco Clement detained, 3 albos, and $1\left[\right.$ album] for the jailer. ${ }^{, 61}$ The initial cost of incarceration, in other words, was equivalent to two days labor for a man and four days for a woman. The incarcerated had to pay for their upkeep, and the revenues from the jail itself were not inconsiderable. In Lucca, the records of revenue kept by the treasury in 1337 recorded that the farm for prison receipts was sold for $£ 8011$ s. 2 d. per month, ${ }^{62}$ for an annual amount of some $£ 967$, or around 280 florins, some 2.7 percent of the 10,365 florins in debt handled through incarceration annually.

The figures provided here are necessarily coarse and involve a good deal of guesswork and extrapolations from recalcitrant evidence. If process was the only thing that mattered we could dispense with the guesswork. But the arguments of this article depend on the claim that the operations of the courts of law in Marseille and Lucca were organized massively around the seizure of goods and bodies for repayment of debt, so numbers, however crude, are essential. So let us accept, as a working hypothesis, the following claims: that two hundred men were arrested for debt annually, many of whom lingered in jail for some time. How does this compare to the number of men arrested and held in prison on criminal charges ranging from crimes of violence to fraud?

In the absence of registers of jail deliveries generated by the criminal courts we 
must return to a seat-of-the-pants estimate. In Lucca, we can count up the number of cases brought before the criminal court each year and subtract the cases of contumacy and banishment. In the last six months of 1331, the treasury collected ninety fines assessed by the criminal court. ${ }^{63}$ Thirty-six were paid over by someone acting on behalf of the criminal, a circumstance suggesting very strongly that the miscreant was not present (typically in self-imposed exile). Fifty-four fines were paid directly by the guilty party over this six-month period, suggesting a maximum annual figure of 108 pre-trial detentions. The partial record from July to October of 1337 suggests an annual figure of 73 incarcerations. Not all criminal cases resulted in guilty sentences, of course, and not all guilty sentences resulted in fines. ${ }^{64}$ Allowing for this, a generous estimate from fragmentary information suggests a total of around pre-trial detentions per year during the 1330s. Arrests for debt were roughly twice as common as pre-trial detentions.

Two other things must be borne in mind. First, the crier-sergeants of Lucca, at least in the first half of the fourteenth century, typically did not arrest individuals accused of crime; instead, the accused usually reported voluntarily to jail. In Lucca, as a result, the spectacle of arrest was a spectacle associated only with debtors. Second, criminal trials in both cities were typically processed within a few days, ensuring that individuals accused of crime spent less time in prison than did debtors. Though the prisons themselves were multi-purpose, they were used more commonly for debtors.

IV

Coercion for debt did not end with incarceration, for creditors had another option: the predation of goods. Predation operated on the principle that material goods constituted a store of value readily liquidated through the process of public auctioning. 
Such was the richness of material culture in northern Italy, southern France, Catalonia, and Valencia by the fourteenth century that there was a lot to prey upon. ${ }^{65}$ Inventories and other records reveal houses chock full of jewelry, fine metalwares, finely appointed bed sets, and luxurious clothes made of richly dyed silks, woolens, and sendals. These items served simultaneously as prestige goods and as fungibles designed to store surplus wealth in a world without banking. The value of movable assets, in many households, was quite significant, easily approaching the value of houses and lands and rental income. The extension of consumer credit undoubtedly fueled patterns of consumption in the fourteenth century. Yet that very culture of debt also enhanced the fungibility of household objects. By the fourteenth century, pawnbrokers, auctioneers, resellers, and regratters were becoming increasingly visible on the urban scene.

The process for seizing goods in Mediterranean Europe is already well known, thanks to the existence of readily accessible normative sources as well as copious records of practice. In Lucca (the situation was almost identical in Marseille), the process began when a creditor came to one of the courts to lodge a claim against a debtor. The frequency is astonishing; n 1338, the civil court of the Podestà di Lucca alone processed 750 simple claims (reclama). ${ }^{66}$ These were not lawsuits; they were similar to the kinds of cases pursued today in small-claims courts. At this point, strategies diverged according to the nature of the circumstances, the preferences of the creditor, or perhaps even the customs of the court. Following one procedure, creditors asked their debtors to appear in court and respond to the claim. Occasionally they did. In February of 1338, for example, an apothecary named Dino Nuccori was dragged into the court by two brothers who claimed $£ 2210$ s. for rent owed on an apothecary’s shop. Dino appeared in court, humbly 
acknowledged the debt, and was ordered to pay up in fifteen days. ${ }^{67}$ The absence of any marginal notes suggests that he complied. In other cases, however, debtors contested the claim (and usually lost) or, far more often, simply failed to appear and were declared contumacious. By way of example, in January of 1338, a smith or a horse master (mariscalchus) of Lucca named Cuccharinus, who was very poor, claimed a debt of $£ 8 .{ }^{68}$ In August of the previous year, the claim went, he had left a pair of iron sleeves (par manicarum de ferro) with another Lucchese as security for a loan of 40s. His creditor, who bore the colorful sobriquet Freelance (Francalancia), had evidently been unwilling or unable to restore the sleeves. Freelance failed to show up at the hearing the following day and was declared contumacious.

Following a second procedure, which could be used in cases where the flight of the debtor was a serious possibility, creditors brought forward their claims but requested that goods be seized immediately and without warning and placed in the hands of a third party, a neighborhood official known as the consul. If not redeemed within three days, the goods sequestered in this way, called res intesite, were then redefined as prede, held for another three days, and then handed over to the creditor. The margins of these acts of intesimentum often include the characteristic phrase preda levata est ("the prey was then seized") followed by the amount and the day. In theory, any seizures should then have been recorded in the acts of predation, and occasionally they were. ${ }^{69}$ However, extensive cross-checking suggests that notaries often did not make the effort.

Regardless of the process, once a claim had been validated and remained unpaid within the time allowed, the creditor could request a license to arrest (licentia capiendi), a license to prey upon the goods of the debtor (licentia predandi), or, in some cases, both. 
In the case above, once Freelance was declared contumacious, the judge authorized a seizure of his goods; a small note in the register declared that a preda (not necessarily the iron sleeves) was seized on 1 March $1338 .^{70}$

In the 1330s, predation was far more common than incarceration, although records suggest that the trend, later in the century, was toward more incarceration. The process was highly regulated and public. Though procedures varied, the creditor's intention to move against the goods was typically conveyed to the debtor by means of a public proclamation, to the sound of trumpets, delivered by one of the crier-sergeants before the house of the debtor and throughout the neighborhood. If the debtor owned or even rented more than one house or workshop, the proclamation could be repeated before each and every one. ${ }^{71}$ In Marseille, seals were placed on doors, warning people not to remove goods without the authorization of the court. Failing any response, the court then proceeded with the seizure of goods by one or more crier-sergeants. In Lucca, the goods were carted off to house of the consul or, sometimes, to the creditor; if the goods were many, porters were hired to help. The crier-sergeant then reported his predation to the notary of the court, who transcribed the list of items seized into his day-book. The debtor was granted a three-day period in which to ransom the goods. If the debtor failed to act, the goods were either auctioned off or simply held indefinitely. In both cities, rules stipulated that the sale had to take place in the accustomed and habitual sites, so as to avoid any appearance of impropriety or price-fixing.

But why seizure? As a rule of thumb, few people in Marseille and Lucca, and perhaps especially debtors, had liquid cash ready to hand. In Marseille, in 1407, an inventory was conducted of the house of a relatively rich decedent. Among all the luxury 
items and other movables they found only four florins and five groats. ${ }^{72}$ Among the hundreds of records of seizures in the archives of Lucca that I have read closely, there is only one in which the crier-sergeant found coins. ${ }^{73}$ Cash lacking, debtors had to liquidate the store of wealth in their own possessions, beginning with movable rather than immovable wealth. There were several ways to liquidate one's goods without having to undergo predation. A court case that unfolded in Marseille in 1407, in which a woman accused a Jewish auctioneer of fraud, shows us an instance in which goods were privately auctioned off. ${ }^{74}$ Beyond that, anyone in need of cash could turn to pawnbrokers, friends, or neighbors, as the smith Cuccharinus himself had done. A large body of evidence points to the massive scale of pawnbroking activities, both professionally, involving career pawnbrokers, and casually, practiced among friends and neighbors.

Predation, in short, was wholly unnecessary: any debtor had the means to liquidate his or her own goods. Yet the practice of predation was extremely common. In Lucca, where the evidence for predation is clearest, the several hundred court registers extant from the 1330s reveal the scale of the practice with great clarity. Among the registers generated by the Court of the Podestà are notebooks, kept on an annual or semiannual basis, that recorded all the seizures undertaken by the crier-sergeants belonging to that court. Some of these are fragmentary. During the first three months of 1333, criers undertook at least 215 seizures in the city of Lucca and its rural district; records are lacking for the rest of the year. For the following year, the records of seizures begin in the last week of May, with 18 seizures. There is then a gap, followed by 78 seizures in the last two weeks of June. July saw 64 and August 93 seizures. At this point the 1334 register peters out. Fortunately, the 1335 register is better: we find 48 seizures in 
November and a minimum of 40 in December. The proportion of seizures seems to follow the agricultural cycle, from a low figure of 40 after the harvest to a high of 156 in June. The average is 75 per month, or roughly 900 per year. This figure is in accordance with a fragment of the register of the Court of the Podestà from 1333 which records not the seizures made but instead the licenses for predation granted to creditors. There, we find a total of 19 licenses granted in a single week, which would be equivalent to 988 per year.

The court of the Podestà was not the only court involved in the profitable business of seizures: at least four other courts kept records of predations. From the sometimes incomplete records, extrapolating where necessary, we can arrive at preliminary figures for the annual number of seizures conducted by these five courts (Table 2). Given the incompleteness of the records, and given also the presence of two or three other courts not included here that might have also been involved in the game of predation, it is likely that the annual figure of 1773 seizures falls considerably short of the annual average. What is more, as noted above, it is very likely that many of the acts of intesimentum resulted in predations that were not consistently recorded in the accounts of predation. Table 2: Approximate Annual Number of Seizures of Goods in Lucca during the 1330s

Name of Court Seizures

Curia della Podestà di Lucca 900

Curia dei Foretani 465

Maggior Sindaco e Giudice degli Appelli 228

Curia dei Visconti o dei Gastaldioni 146

Curia delle Querimoniae $\quad 34$ 


\section{Total 1773}

It is important to bear in mind that many of these seizures involved residents of Lucca's rural district. Unfortunately, the debtor's domicile is not usually indicated in the notebooks. Where indicated, however, it appears that around two-thirds of the seizures derived from the district. In the 1330s, the city of Lucca had a population of perhaps 20,000 , suggesting an absolute minimum of around 600 seizures annually within the city walls. Even allowing for the fact that some of the debtors surely appeared more than once, it is possible that one in ten households in the city suffered an act of predation every year.

For a predatory crier-sergeant, a debtor's house offered a range of seizable goods. The goods seized in the countryside most often took the form of commodities like oil, wine, fava beans, millet, and wheat. Since it would have been expensive and timeconsuming to carry these heavy, low-value goods into the city, crier sergeants almost always left them with the consul of the village, leaving it to them to arrange for shipping the goods to Lucca. Within Lucca itself, it was possible to find houses that had been entirely stripped of seizable assets; these are noted in notebooks entitled "Accounts of Seizures Not Found." Some of these cases surely arose from the absolute poverty of debtors, although it is quite clear that debtors had numerous ways to spirit goods out of their houses in the days leading up to predation.

Not everything was fair game. In both Italy and Spain, according to Gian Maria Varanini and Antoni Furió, municipal statutes often forbade the seizure of tools and animals. ${ }^{75}$ In Verona, the list of prohibited items included iron and copper tools, clothing, 
beds and other furniture, tools, and animals. Crier-sergeants operating within the city of Lucca itself showed a preference for clothing: tunics, surcoats, cloaks, and capes. The notaries often noted down the colors as well as trims used, including vair, muslin, and other fine fabrics. Many of the articles of clothing listed in the Lucchese records were identified as masculine or feminine; this gendering extended to blankets and even mattresses. Crier-sergeants also seized coffers, bolts of fabric, hand- and face-towels, and ironwares. In Marseille, registers of seizures are not as common, and it is less easy to establish the range of items seized. In the extant records, I have come across a silver belt, a crown studded with pearls, a book, two silver goblets, a green cape, a golden pot or vase (potum) decorated with pearls and precious stones, sails, and a bed. There are also foodstuffs, though much fewer than in Lucca.

How shall we approach these lists of objects seized? To begin with, at least where cityfolk are concerned, it is possible to discern a preference for clothing and fine goods over commodities or ironwares. From the evidence of inventories in Marseille, it is clear that every house had a pantry or larder where the household kept food supplies. These were highly fungible items of known value, and thus, in theory, should have been ideal objects of seizure. In addition, the pantry was often located near the door, right off the hallway leading into the house. Thus, food supplies would have been the among the first items to attract attention. Despite this, crier-sergeants usually walked right by the pantry, the kitchen, and the dining hall so as to get into the bedrooms and other rooms. They seem to have preferred goods that carried the identity of the owner, clothing above all.

As Furió has noted, most seizures did not result in auctions. Goods were sometimes ransomed by their owners, and in other cases the creditors simply held on to 
them as if they were hostages. In Lucca, perhaps one in ten seizures led to an auction. Where we do find auctions, they were far more likely to involve identity objects: although foodstuffs constituted around two-fifths of all objects listed in the inventories of seizures in Lucca, they were only one-seventh of the goods actually sold at auction. Creditors showed a marked preference for exposing the more personal objects to the potential humiliation of the auction.

The several dozen records of auctions I have consulted sometimes reveal a gap between the nominal value of the item seized and the amount earned at auction. ${ }^{76}$ In one case from Lucca in 1333, a ring was seized for a debt of 56s. and sold at auction for $34 \mathrm{~s}{ }^{77}$ It is easy to appreciate the difficulty of estimating, on the spot, the value of a ring. Yet the pattern persists in other records. A lady’s tunic and a robe seized for a debt of $£ 8$ and sold at auction, six weeks later, for £6. A lady’s tunic and a silken corset, in a fine green color and trimmed with yellow muslin, seized for a debt of $£ 12$ and sold for $£ 2$. A particularly striking case involved several sestiers of wine seized for a debt of $£ 9$ and sold for £4. Is it possible that the crier-sergeant in this case could have made an error of such magnitude?

In the absence of compelling evidence, let us suppose that a gap between the original debt and the result of the sale at auction was the norm. What would account for this gap? This question brings us back to the curious question raised earlier: why were there seizures in the first place?

Given that there were plenty of ways to liquidate one's own goods so as to pay off a debt, we have to assume that debtors deliberately pursued the path that led to predation. It may have been shameful for creditors to insist on repayment, a situation that allowed 
debtors to game the system. In addition, it is quite likely that seizure cost the debtor less than liquidating the goods himself or herself. ${ }^{78}$ Almost all loans, including pawns, involved some degree of interest payments. Items left in pawn, moreover, had a value as much as two to three times greater than the amount paid, and if this sum wasn't repaid in time the pawned items could be lost. The ever-present concerns about usury, in fact, remind us that it is possible that creditors asked crier-sergeants to aim for goods worth less than the nominal debt so as to avoid accusations of usury. Yet there is another way of looking at this issue. If the public humiliation of the debtor constituted a sort of negative symbolic capital, the sum of the debt would have been reached by adding the amount earned at auction to the price of the humiliation inflicted on the debtor. From the debtor's point of view, one lost face, but at the same time lost less money.

Humiliation, as Gian Maria Varanini and others have shown, was omnipresent where debt is concerned..$^{79}$ In some Italian cities, the names of debtors were read out at Sunday mass in the city's cathedral. In Como, the debtor, stripped down to a shirt and bereft of britches, had to stand on a podium before the crowd and expose his rear-end three or four times to the public assembly. In Florence, the portraits of debt fugitives, the pitture infamante, were painted on the sides of houses. ${ }^{80}$ When predation came into play, however, the object of humiliation turned from the person of the debtor to the object of seizure, and the humiliation itself became vicarious. The process began with the public announcement of the intention to seize goods, made to the sound of blaring trumpets before the house of the debtor or the felon and in all the public places of the neighborhood. The seizure itself involved sergeants entering a house, rifling through the goods, and taking what they pleased. The goods, like hostages, were carted off through 
the streets to the houses of creditors or third-party sureties. Some were then exposed on the auction block. In Marseille, the auctioneers were invariably Jewish brokers, which perhaps added to the indignity.

It stands to reason that humiliation was embedded in the process of debt recovery, in much the same way that penal law deliberately exposed the condemned to spectacles of shame and humiliation. ${ }^{81}$ This was an age, after all, in which the sources of honor were shifting ever more into the possession and display of material wealth. Archaeologically, we see this in the emergence of a whole new range of buttons, buckles, pins, and other fasteners, including knock-offs of gold and silver fasteners made with tin and pewter. In inventories from the fourteenth century, we find amazing descriptions of things that don't show up so commonly in the archeological record, including finewares, fabrics, and clothes. In a world of artisanal production and familial transmission, a world in which all goods, even clothes, had relatively long life-histories, goods had time to accrue sentimental value and embed themselves in the household as if they were members of the family. The acts of resistance to predation that we sometimes find make the most sense if we understand the following point: the seizure and sale of goods was like the taking of hostages. ${ }^{82}$

In his study of the penal system of Old Regime France, Richard Mowery Andrews provides a list of some twenty-five or more punishments that could be applied to the condemned. The Criminal Ordinance of 1670 groups them into three areas: nondefaming, defaming, and afflictive. Nondefaming punishments consisted of alms, warnings, or suspensions from office. Afflictive punishments range from banishment to execution. Fines are included on the list of defaming punishments, punishments that were designed 
to "dishonor the guilty person and make him infamous." ${ }^{83}$ At first blush this seems very peculiar. Why should fines be dishonoring and infamous? It is only when we understand the humiliation built into the system that the nature of the penalty becomes clear.

V

The regulation of debt was, by a distance, the major preoccupation of courts of law in the two cities studied here. Records from Lucca and Marseille suggest that simple instances of debt recovery were at least three to four times more common than criminal prosecutions. The practice of contumacy, moreover, means that court personnel were little involved in arresting criminals. Crier-sergeants spent considerably more time on debt recovery than on criminal matters - and were well paid for their actions, since they garnered a fixed percentage from every seizure they made. Debt recovery has the appearance of a purely economic concern, and that is how it has been treated in the literature. But to write about debt recovery as an economic matter is just as anachronistic as to speak of contumacy as a sign of impotent justice. The culture of debt was a culture of honor, shame, and humiliation. The considerable investment made in the infrastructure of coercion for debt is a sign that late medieval courts of law, before anything else, were engaged in the regulation of honor. This is also why they meddled in face-to-face honor contests. They did so not because street fights were violent per se, but because they involved honor and standing. With this understanding, we can more easily understand why courts routinely transformed violent offenders into debtors. Indebtedness, in this world, was a vector for shame.

For decades, the history of late medieval justice was driven by the hyper-statist narrative with which I began this paper: private violence gave way to public violence as 
late medieval states asserted their monopoly on the legitimate exercise of force. But as we have moved more deeply into the records of practice, a different vision has appeared. Late medieval penal justice could indeed be violent at times. But if Lucca and Marseille are at all representative, the court system of late medieval Mediterranean Europe was not especially violent toward the bodies of the violent. Acting at the behest of creditors, not on behalf of some thinking, planning state, the courts practiced their violence more often on debtors and especially on goods and things. It was in this arena that late medieval states first began to develop, serendipitously, the instruments and apparatus of coercion that Max Weber, a century ago, took to be the signature of a mature state. Only later was the infrastructure of coercion deployed to the ends that Weber, and generations of medieval historians after him, imagined they were designed for. 
Note

${ }^{1} \mathrm{I}$ have presented these and related arguments at workshops and talks at Denison College, the University of Minnesota, the University of Ottawa, the University of Wisconsin-Madison, the University of Michigan, the University of Toronto, Yale University, Harvard University, Stanford University, the Universite de Paris I PanthéonSorbonne, the École Pratique des Hautes Études, Dumbarton Oaks, the Universität Bielefeld, Auxerre, Venice, and the American Historical Association convention. I am immensely grateful to my hosts for their invitations and to many friends and colleagues for their feedback, and also wish to express my profound thanks to Christine Meek and Dott. Sergio Nelli for guiding me through the Lucchese archives.

${ }^{2}$ From the Library of Latin Texts and the Monumenta Germaniae Historica, which I consulted at http://www.brepolis.net.ezp1.harvard.edu/login/overview.cfm. For the sake of simplicity I considered only nominative, accusative, and ablative forms in the singular of the following words: violentia, iusticia, invidia, and vindicta. I normalized the frequency relative to appearances of $e t$, a word of relatively unvarying frequency.

${ }^{3}$ Self and Society in Medieval France: The Memoirs of Abbot Guibert of Nogent, ed. John F. Benton, trans. C. C. Swinton Bland (New York: Harper and Row, 1970), 3.11. ${ }^{4}$ See, among others, Oliver J. Thatcher and Edgar H. McNeal, A Source Book for Mediaeval History: Selected Documents Illustrating the History of Europe in the Middle Age (New York: Charles Scribner's Sons, 1905). Weber's classic statement was published in 1919; see Max Weber, "Einleitung," in Politik als Beruf, http://www.textlog.de/weber_politik_beruf.html, accessed 30 June 2010.

${ }^{5}$ Marc Bloch, Feudal Society, trans. L.A. Manyon (Chicago: University of Chicago 
Press, 1971), 73. For interpretations, see Stephen D. White, “The Politics of Anger," in Anger's Past: The Social Uses of an Emotion in the Middle Ages, ed. Barbara H.

Rosenwein, 127-52 (Ithaca: Cornell University Press, 1998), 127-28.

${ }^{6}$ Important works include Jacques Chiffoleau, Les justices du pape: délinquance et criminalité dans la region d'Avignon au quatorzième siècle (Paris: Publications de la Sorbonne, 1984); Nicole Gonthier, Le châtiment du crime au Moyen Âge (Rennes:

Presses Universitaires de Rennes, 1998); Robert Muchembled, Le temps des supplices: de l'obéissance sous les rois absolus, XVe-XVIIIe siècle (Paris: A. Colin, 1992).

${ }^{7}$ Esther Cohen, The Crossroads of Justice: Law and Culture in Late Medieval France (Leiden: E. J. Brill, 1993).

${ }^{8}$ Michel Foucault, Discipline and Punish: The Birth of the Prison, trans. Alan Sheridan (New York: Pantheon Books, 1977); for a critique, see Richard Mowery Andrews, Law, Magistracy, and Crime in Old Regime Paris, 1735-1789, vol. 1, The System of Criminal Justice (Cambridge: Cambridge University Press, 1994).

${ }^{9}$ Foucault, Discipline and Punish, 8. See Karl Shoemaker, “The Problem of Pain in Punishment: A Historical Perspective," in Pain, Death, and the Law, ed. Austin Sarat, 15-41 (Ann Arbor: University of Michigan Press, 2001).

${ }^{10}$ For the art historical evidence, see Mitchell B. Merback, The Thief, the Cross, and the Wheel: Pain and the Spectacle of Punishment in Medieval and Renaissance Europe (Chicago: University of Chicago Press, 1999).

${ }^{11}$ Mark D. Meyerson, Daniel Thiery, and Oren Falk, eds., "A Great Effusion of Blood”?: Interpreting Medieval Violence (Toronto: University of Toronto Press, 2004), 6.

12 Thomas N. Bisson, "The 'Feudal Revolution'," Past and Present 142 (1994): 6-42. 
${ }^{13}$ Chris Wickham, Legge, pratiche e conflitti: Tribunali e risoluzione delle dispute nella Toscana del XII secolo (Rome: Viella, 2000).

${ }^{14}$ William Ian Miller, Bloodtaking and Peacemaking: Feud, Law, and Society in Saga Iceland (Chicago: University of Chicago Press, 1990); idem, Humiliation: And Other Essays on Honor, Social Discomfort, and Violence (Ithaca: Cornell University Press, 1993).

${ }^{15}$ Robert Bartlett, The Making of Europe: Conquest, Colonization, and Cultural Change, 950-1350 (Princeton: Princeton University Press, 1993), 86-89.

${ }^{16}$ This was the explicit goal of some of the most formative work; see, among others, Fredric L. Cheyette, "Suum cuique tribuere," French Historical Studies 6 (1970) 287-99; Stephen D. White, "Feuding and Peacemaking in the Touraine around the Year 1100," Traditio 42 (1986): 195-263; Patrick Geary, "Vivre en conflit dans une France sans état: typologie des mécanismes de règlement des conflits (1050-1200)," Annales: Économies, Sociétés, Civilisations 41 (1986): 1107-33.

${ }^{17}$ See Walter Benjamin, Selected Writings, vol. 1, 1913-1926, trans. Rodney Livingstone and others, ed. Michael W. Jennings, Howard Eiland, and Gary Smith (Cambridge, Mass.: Belknap, 1996), 236-52.

${ }^{18}$ Andrea Zorzi, "The Judicial System in Florence in the Fourteenth and Fifteenth Centuries," in Crime, Society and the Law in Renaissance Italy, ed. Trevor Dean and K.J.P. Lowe, 40-58 (Cambridge: Cambridge University Press, 1994); idem, “La cultura della vendetta nel conflitto politico in età comunale," in Le storie e la memoria. In onore di Arnold Esch, ed. Roberto Delle Donne and Andrea Zorzi, 135-170 (Florence: Firenze University Press, 2002); Mark D. Meyerson, The Muslims of Valencia in the Age of 
Fernando and Isabel: Between Coexistence and Crusade (Berkeley: University of California Press, 1991); Peter Schuster, Eine Stadt vor Gericht: Recht und Alltag im spätmittelalterlichen Konstanz (Paderborn: Schöningh, 2000); Paul Hyams, Rancor and Reconciliation in Medieval England (Ithaca: Cornell University Press, 2003); Xavier Rousseaux and René Lévy, eds., Le pénal dans tous ses états: justice, états et sociétés en Europe (XII $-X X^{e}$ siècles) (Brussels: Facultés universitaires Saint-Louis, 1997); Jeppe Büchert Netterstrøm and Bjørn Poulsen, eds., Feud in Medieval and Early Modern Europe, ed. (Aarhus, Denmark: Aarhus University Press, 2007).

${ }^{19}$ Claude Gauvard, "De grace especial": crime, état, et société à la fin du Moyen Âge, 2 vols. (Paris: Publications de la Sorbonne, 1991); see also Natalie Zemon Davis, Fiction in the Archives: Pardon Tales and Their Tellers in Sixteenth-Century France (Stanford: Stanford University Press, 1987); Helen Lacy, The Royal Pardon: Access to Mercy in Fourteenth-Century England (York: York Medieval Press, 2009).

${ }^{20}$ My emphasis is Lucca since I have explored Marseille elsewhere; see The Consumption of Justice: Emotions, Publicity, and Legal Culture in Marseille, 1264-1423 (Ithaca: Cornell University Press, 2003).

${ }^{21}$ For a general introduction and orientation to the literature, see the first chapter of my Imaginary Cartographies: Possession and Identity in Late Medieval Marseille (Ithaca: Cornell University Press, 1999).

${ }^{22}$ For Lucchese history, see, among others, Louis Green, Castruccio Castracani: A Study on the Origins and Character of a Fourteenth-Century Italian Despotism (Oxford: Clarendon Press, 1986); Christine Meek, Lucca 1369-1400: Politics and Society in an Early Renaissance City-State (Oxford: Oxford University Press, 1978); eadem, The 
Commune of Lucca under Pisan Rule, 1342-1369 (Cambridge, Mass.: The Mediaeval Academy of America, 1980); Michael E. Bratchel, Medieval Lucca and the Evolution of the Renaissance State (Oxford: Oxford University Press, 2008).

${ }^{23}$ In Marseille, the Latin word for seizure was sazimentum and the object of seizure, more often than not, was simply called a pignus (English, a "pawn"; mod. French, a gage).

${ }^{24}$ Charles Tilly, "War Making and State Making as Organized Crime," in Bringing the State Back In, eds. Peter B. Evans, Dietrich Rueschmeyer, and Theda Skocpol, 169-91 (Cambridge: Cambridge University Press, 1985).

${ }^{25}$ As Rees Davies has reminded us, it is easy to overlook "the interstitial and noninstitutionalized forms of power." Rees Davis, "The Medieval State: The Tyranny of a Concept?," Journal of Historical Sociology 16 (2003): 280-300, here 291-92.

${ }^{26}$ Archivio di Stato di Lucca (hereafter ASL), Podestà di Lucca (hereafter PdL) 4725, fols. $2 \mathrm{v}, 3 \mathrm{r}, 4 \mathrm{v}, 5 \mathrm{r}$.

${ }^{27}$ In addition to the literature cited in my Consumption of Justice, see Hanna Zaremska, Les bannis au Moyen Âge, trans. Thérèse Douchy (Paris: Aubier, 1996); David Potter, “"Rigueur de Justice': Crime, Murder and the Law in Picardy, Fifteenth to Sixteenth Centuries," French History 11 (1997): 265-309, here 274, 284, and passim; Robert C. Davis, "The Renaissance Goes Up in Smoke," in The Renaissance World, ed. John Jeffries Martin, 398-411 (New York: Routledge, 2007), here 399; Gerd Schwerhoff, "Justice et honneur. Interpréter la violence à Cologne $\left(\mathrm{XV}^{\mathrm{e}}-\mathrm{XVIII}\right.$ siècle), Annales. Histoire, Sciences Sociales 5 (2007): 1031-61, here 1048.

${ }^{28}$ Eg. Bernard Guenée, Tribunaux et gens de justice dans le bailliage de Senlis à la fin du 
Moyen Âge (Paris, 1963), 293-5; Chiffoleau, Les justices du pape, 44.

${ }^{29}$ Meyerson et al., Great Effusion of Blood, 6.

${ }^{30}$ Julius R. Ruff, Violence in Early Modern Europe 1500-1800 (Cambridge: Cambridge University Press, 2001), 44.

${ }^{31}$ ASL PdL 4717, fols. 2r-3r.

${ }^{32}$ The court notary who kept a register from October of 1339 to March of 1340 was especially attentive to the several forms of summoning and distinguished carefully between citations issued in person and citations issued to the house, via the family. See ASL PdL 4739: respectively se citasse dictum inquisitum personaliter and se citasse dictum inquisitum domo in familia.

${ }^{33}$ Statutum Lucani Communis, ed. Salvatore Bongi, presentazione di Vito Tirelli (Lucca: Maria Pacini Fazzi editore, reprint edition 1991 [1867]), bk 3, ch. 2, pp. 132-133: Et si probaretur de ipso maleficio vel iniuria, ad condepnationem faciendam procedere debeant; non obstante quod de iure comuni absens condenpnari non possit.

${ }^{34}$ ASL, Sentenze e bandi (hereafter SeB) 2.

${ }^{35}$ ASL SeB 7. By way of comparison, Peter Raymond Pazzaglini has counted up 1,600 acts of banishment in Siena in the space of a little over two years earlier in the fourteenth century; see The Criminal Ban of the Sienese Commune, 1225-1310 (Milan: A. Giuffrè, 1979), 34.

${ }^{36}$ ASL PdL 4739. The register opened on 6 October 1339 and closed on 8 March of the following year.

${ }^{37}$ In six cases, including one involving a petty insult, the accused were simply released, and in a further four cases involving groups the outcomes were mixed. 
${ }^{38}$ Whereas in Lucca, assailants appear to have slipped straight into self-imposed exile, in Marseille, as in London, escape was a two-stage process, beginning with sanctuary in church. See Gervase Rosser, "Sanctuary and Social Negotiation in Medieval England," in The Cloister and the World: Essays in Medieval History in Honour of Barbara Harvey, ed. John Blair and Brian Golding, 57-70 (Oxford: Oxford University Press, 1996). On the law of sanctuary, see Karl Shoemaker, Sanctuary and Crime in the Middle Ages, 4001500 (New York: Fordham University Press, 2011).

${ }^{39}$ Archives départementales des Bouches-du-Rhône (hereafter ADBR) 3B 96.

${ }^{40}$ I have translated these acts in Daniel Lord Smail and Kelly Gibson, eds., Vengeance in Medieval Europe: A Reader (Toronto: University of Toronto Press, 2009), 417-27.

${ }^{41}$ ASL PdL 4739.

${ }^{42}$ ASL PdL 4721.

${ }^{43}$ ASL, Curia dei ribelli e dei banniti, 6.

${ }^{44}$ Katherine Ludwig Jansen, "Florentine Peacemaking: the Oltrarno, 1287-1297," in Pope, Church and City: Essays in Honor of Brenda Bolton, ed. Frances Andrews, Christoph Egger, and Constance M. Rousseau, 327-44 (Leiden: Brill, 2004); Andrea Zorzi, ed.. Conflitti, paci e vendette nell'Italia comunale (Florence: Firenze University Press, 2009).

${ }^{45}$ ASL PdL 4739, 3 Dec. 1339.

${ }^{46}$ Statutum Lucani Communis, bk 2, ch. 23, p. 85.

${ }^{47}$ Jean-Louis Gaulin, "Les registres de bannis pour dettes à Bologne au XIII ${ }^{\mathrm{e}}$ siècle: une nouvelle source pour l'histoire de l'endettement," in Mélanges de l'École française de Rome. Moyen-Age, Temps modernes, vol. 109 (1997): 479-99. 
${ }^{48}$ Margot C. Finn, The Character of Credit: Personal Debt in English Culture, 17401914 (New York: Cambridge University Press, 2003); V. Markham Lester, Victorian Insolvency: Bankruptcy, Imprisonment for Debt, and Company Winding-Up in Nineteenth-Century England (Oxford: Clarendon Press, 1995).

${ }^{49}$ See Julie Claustre, Dans les geôles du roi. L'emprisonnement pour dette à Paris à la fin du Moyen Âge (Paris: Publications de la Sorbonne, 2007); Guy Geltner, The Medieval Prison: A Social History (Princeton: Princeton University Press, 2008).

${ }^{50}$ ADBR 3B 822, fol. 75r, case opened 24 Nov. 1357 on fol. 67r. See also 355E 9, fols. 47r-48r, 8 June 1358.

${ }^{51}$ ADBR 3B 808, fols. 290r-303v, case opened 28 Nov. 1342.

${ }^{52}$ ADBR 3B 19, fols. 11r-20v, case opened 23 Dec. 1325.

${ }^{53}$ ADBR 3B 42, fols. 14r-31v, case opened 24 July 1341, in which the merchant Antoni Catalan had Johan Esteve imprisoned for debt; ADBR 3B 29, fols. 75r-79r, case opened 19 July 1334, in which a merchant from Narbonne is imprisoned in Marseille at the behest of another Narbonnais merchant; for the wine-seller, see ADBR 3B 3B 37, fols. 264r-269r, case opened May or June 1339 (date illegible).

${ }^{54}$ ADBR 3B 57, fols. 2r-19v, case opened 8 Oct. 1354.

${ }^{55}$ ADBR 3B 30, fols. 3r-8v, case opened 18 Mar. 1335.

${ }^{56}$ ADBR 355E 10, fol. 38v, 14 Aug. 1359 shows how oathswearers could help get people released from jail; in 355E 10, fol. 18v, 8 May 1359, a woman stands surety for her husband in jail for debt.

${ }^{57}$ ASL PdL 33, fol. 101r and following.

${ }^{58}$ ASL, Opera di Santa Croce 9, fols. 148r-155r. 
${ }^{59}$ The florin, at this time, was being exchanged for 69 Lucchese shillings, and a staria of wheat cost around $12 \frac{1}{2}$ Lucchese shillings. I do not yet have price data on some of the other commodities listed in the register.

${ }^{60}$ I have yet to discover a record from Lucca that records the fees.

${ }^{61}$ ADBR 3B 822, fol. 75r, case opened 24 Nov. 1357 on fol. 67 r.

${ }^{62}$ ASL, Camarlingo Generale (hereafter CG) 15, fol. 196r: Titulus pecunie percepte de proventu carcerarum.

${ }^{63}$ ASL CG 4, fols. 94r-114r.

${ }^{64}$ Records of the criminal court of the Podestà suggest that two-thirds of the cases resulted in convictions, indicating an annual total of around 250 criminal inquests during the 1330 s.

${ }^{65}$ Richard A. Goldthwaite, Wealth and the Demand for Art in Italy, 1300-1600 (Baltimore: Johns Hopkins University Press, 1995); Susan Mosher Stuard, Gilding the Market: Luxury and Fashion in Fourteenth-century Italy (Philadelphia: University of Pennsylvania Press, 2006); Maryanne Kowaleski. "A Consumer Economy," in A Social History of England, 1200-1500, ed. Rosemary Horrox and W. Mark Ormrod, 238-59 (Cambridge: Cambridge University Press, 2006); Michelle O’Malley and Evelyn Welch. The Material Renaissance (Manchester: Manchester University Press, 2007). ${ }^{66}$ One of the most common registers found in the records of the Lucchese courts was one entitled Liber reclamorum, or "Book of Claims."

${ }^{67}$ ASL PdL 79, fols. 90r-91r.

${ }^{68}$ Ibid., fol. $28 \mathrm{v}$.

${ }^{69}$ See ASL, Curia Nuova di Giustizia e dell'Esecutore 32. Fol. 25r of this register records 
an act of intesimentum with a marginal notice of predation. The formal record of the predation appears on fol. 101r.

${ }^{70}$ Ibid.: (the marginal notes are heavily abbreviated): $P[$ reda] l[evata] e[st] $d[i e]$ p[rima] Marcii in libris decem d[enariorum] et expensis et sic p[ro]n[unciata] per jud[icem].

${ }^{71}$ E.g. ASL, Curia dei Rettori 11, p. 290: Et publice et alta voce ad domum eius habitationis et per dictam contratam in vicinia publice et alta voce cum proclamatione dicti nuncii et tunc in dictis locis eidem Johanni locasse.

${ }^{72}$ ADBR 3B 145, fols. 97v, case opened 17 June 1405 on fol. 94r.

${ }^{73}$ ASL, Curia dei Visconti o dei Gastaldioni 24, fol. 54r.

${ }^{74}$ ADBR 3B 859, fol. 133r, case opened 26 Apr. 1408 on fol. 105 r.

${ }^{75}$ Gian Maria Varanini, "Tra fisco e credito: note sulle camere dei pegni nelle città venete del Quattrocento," Studi storici Luigi Simeoni 33 (1983): 215-46; Antoni Furió, “Crédit, endettement et justice: prêteurs et débiteurs devant le juge dans le royaume de Valence (XIII ${ }^{\mathrm{e}}-\mathrm{XV}^{\mathrm{e}}$ siècle), in La dette et le juge: juridiction gracieuse et juridiction contentieuse du XIII ${ }^{e}$ au XV $V^{e}$ siècle (France, Italie, Espagne, Angleterre, Empire), ed. Julie Claustre, 19-53 (Paris: Publications de la Sorbonne, 2006).

${ }^{76}$ Regrettably, such records are relatively uncommon; further research may turn up more. ${ }^{77}$ ASL PdL 33, fol. 137r.

${ }^{78}$ A record of the Curia di San Christoforo from 1315 shows that court costs for predation were fixed at one penny for every $60 \mathrm{~d}$., or 1.67 percent. See the list of court receipts in ASL, Curia di San Christoforo 24, fol. 42r ff. Later in the century, court costs grew to 4 or 5 percent. 
${ }^{79}$ Varanini, "Tra fisco e credito."

${ }^{80}$ Samuel Y. Edgerton, Pictures and Punishment: Art and Criminal Prosecution during the Florentine Renaissance (Ithaca: Cornell University Press, 1985).

${ }^{81}$ For some of the ways in which shame was leveraged in debt recovery, see Peter Schuster, "The age of debt? Private Schulden in der spatmittelalterlichen Gesellschaft," in Schuldenlast und Schuldenwert. Kreditnetzwerke in der europäischen Geschichte 1300-1900, ed. Gabriele Clemens, 37-52 (Trier: Kliomedia, 2008). The recent literature on shaming punishments in criminal context is surveyed in Jörg Wettlaufer, "Beschämende Strafen in Westeuropa und Ostasien. Zwischenbericht zu einem kulturvergleichenden Forschungsprojekt zum Spätmittelalter und der Frühen Neuzeit,” forthcoming.

${ }^{82}$ The scale of resistance may have been significant. According to Michael Bratchel, nearly 10 percent of the crimes prosecuted in one of Lucca's courts between 1441 and 1461 were acts of resistance to agents of the court, and many of these would have arisen from processes of debt recovery. See "Criminality, the Criminal Records and the Reconstruction of Social Realities: The Example of Late Medieval Tuscany,” The Southern African Journal of Medieval and Renaissance Studies 7 (1997): 37-47, here 42.

${ }^{83}$ Andrews, Law, Magistracy, 309. 